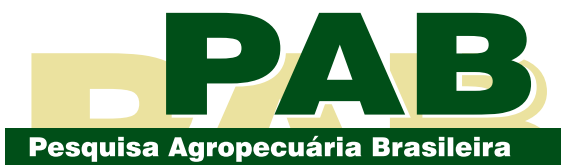

ISSN 1678-3921

Journal homepage: www.embrapa.br/pab

For manuscript submission and journal contents, access: www.scielo.br/pab

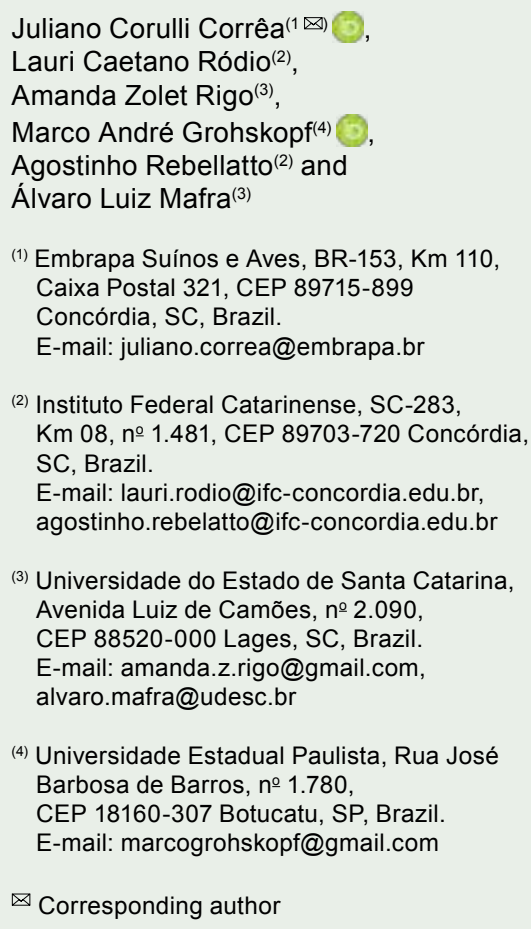

(4) Universidade Estadual Paulista, Rua José Barbosa de Barros, № 1.780 , CEP 18160-307 Botucatu, SP, Brazil. E-mail: marcogrohskopf@gmail.com

$\bowtie$ Corresponding author

Received

October 27, 2017

Accepted

March 20, 2019

How to cite

CORRÊA, J.C.; RÓDIO, L.C.; RIGO, A.Z.; GROHSKOPF, M.A.; REBELLATTO, A.; MAFRA, Á.L. Carbon fractions and stock in response to solid and fluid organomineral fertilizers in highly fertile soils. Pesquisa Agropecuária Brasileira, v.54, e00266, 2019. DOI: https://doi.org/10.1590/S1678-3921. pab2019.v54.00266.

\title{
Carbon fractions and stock in response to solid and fluid organomineral fertilizers in highly fertile soils
}

\begin{abstract}
The objective of this work was to evaluate the effect of the application of organomineral and mineral fertilizers to highly fertile soils on the carbon management index (CMI) and carbon fractions and stock. The experiment was carried out on an Oxisol and Inceptisol, under no-tillage, in three crop seasons. The treatments consisted of two organomineral fertilizers and of two mineral fertilizers in solid and fluid forms, besides a control without fertilization. The application of organomineral and mineral fertilizers, in solid and fluid forms, to the different soil classes with high fertility promoted changes in total organic carbon, particulate organic carbon, and carbon associated with minerals, as well as in carbon stocks and the CMI. In the treatments with fluid mineral fertilizer and solid organomineral fertilizer, such changes occurred only in the Inceptisol due to the lower degree of weathering of this soil. The higher values of the CMI, with the fluid mineral fertilizer in the Inceptisol, allow inferring on which would be the best management practice aiming at the increase and maintenance of carbon in the soil-plant system, based on the yield results of wheat, sorghum, and corn, which were similar to those obtained with the other fertilizers.
\end{abstract}

Index terms: fluid fertilizer, no-tillage, organomineral fertilizer.

\section{Frações e estoque de carbono em resposta a fertilizantes organominerais sólido e fluido em solos com fertilidade construída}

Resumo - O objetivo deste trabalho foi avaliar o efeito da aplicação de fertilizantes organominerais e minerais em solos com fertilidade construída sobre o índice de manejo de carbono (IMC) e as frações e o estoque de carbono. $\mathrm{O}$ experimento foi realizado em um Cambissolo e em um Nitossolo sob sistema plantio direto, por três anos agrícolas. Os tratamentos consistiram de dois fertilizantes organominerais e de dois fertilizantes minerais nas formas sólidas e fluídas, além do controle sem adubação. A aplicação de fertilizantes organominerais e minerais, nas formas sólidas e fluídas, às diferentes classes de solo com fertilidade construída, promoveu alterações no carbono orgânico total, particulado e associado aos minerais, bem como nos estoques de carbono e no IMC. Nos tratamentos com fertilizante mineral fluído e fertilizante organomineral sólido, houve alterações apenas no Cambissolo, em razão do menor grau de intemperização deste solo. Os maiores valores do IMC, com fertilizante mineral fluido no Cambissolo, permitem inferir sobre qual seria a melhor prática de manejo para o aumento e a manutenção de carbono no sistema solo-planta, justificada pelos resultados de produtividade de trigo, sorgo e milho, que foram semelhantes aos obtidos com os outros fertilizantes.

Termos para indexação: fertilizante fluido, plantio direto, fertilizante organomineral. 


\section{Introduction}

Soil organic matter (SOM) participates in various biological, chemical, and physical soil processes that determine the productive potential of the soil (Mafra et al., 2014). Organic carbon (OC) is the main constituent of SOM which is influenced by the soil class characteristics and soil management system (McCarthy et al., 2008), including the fertilization practice, with both inorganic and organic fertilizers (Corrêa et al., 2018a).

The choice of how, when, and at what dose fertilizers should be applied to soils allows of variations in the OC accumulation (Mafra et al., 2015). Criteria for the method of fertilization should therefore be adopted, in order to enable an increased OC, and a reduced OC decomposition rates in the soil (Sá et al., 2014). The application of fertilizers promotes changes in the OC fractions in the soil in medium and long-term tillage systems (Karhu et al., 2012), whereas, in short-term ones, such increases may or may not occur (Wu et al., 2004; Šimon, 2008).

Methodologies for the evaluation of fertilizer efficiency on $\mathrm{OC}$ alteration in a short-term include the analysis of particulate organic carbon (POC), carbon associated with minerals (CAM), and subsequent calculation of the carbon management index (CMI) (Conceição et al., 2014; Mafra et al., 2015).

Criteria supporting the clarification of this assertion consistently state that: POC is present for the shortest length of time in the soil, and it is characterized by labile carbon, being the first fraction to reflect changes in the C content in the soil (Conceição et al., 2013). CAM, meanwhile, is the fraction that interacts with mineral particle surfaces, forming clay-metal-humus complexes and representing the SOM in an advanced state of stability and greater recalcitrance (Christensen, 2001).

Among the parameters used to determine the soil quality, CMI allows of one to ascertain whether good fertilization practices increase the admission of $\mathrm{OC}$ in the system. CMI is a useful tool to subsidize information on the best soil management systems (Nicoloso et al., 2008), as it takes into account the lability, and the quantitative and qualitative characteristics of the SOM (Schiavo et al., 2011).

Changes in the fractions of carbon in the soil (POC and CAM) and, consequently, their quality (CMI) and stock depend on the quantity and quality of the fertilizer to be applied, which is intrinsically related to the soil class and production system used. The region of western Santa Catarina is characterized by clayey soils (Oxisol and Inceptisol) of high-aggregate stability, with high levels of nutrients as a result of the intense and frequent use of fertilizers (Correa et al., 2018b).

The knowledge about fractions and carbon stock in a no-tillage system, with the application of organomineral fertilizers, would allow of the recommendation of good practices for the type and physical form of the fertilizer, and dose, location, and timing of the application, focusing on the accumulation of $\mathrm{OC}$ in different sized aggregates in soils with constructed fertility.

The objective of this work was to evaluate the effect of the application of organomineral and mineral fertilizers to highly fertile soils on the carbon management index and carbon fractions and stock.

\section{Materials and Methods}

The experiment was carried out in field conditions, during the agricultural years of 2010/2011, 2011/2012, and 2012/2013, in the municipality of Concórdia $\left(27^{\circ} 14^{\prime} 2^{\prime \prime} \mathrm{S}\right.$ and $52^{\circ} 11^{\prime} 40^{\prime \prime} \mathrm{W}$, at $569 \mathrm{~m}$ altitude), in the state of Santa Catarina, Brazil. The climate is humid subtropical (Cfa), according to the Köppen-Geiger's classification, with an annual mean rainfall of over $1,500 \mathrm{~mm}$, which is well distributed throughout the year, and an annual mean temperature of $15^{\circ} \mathrm{C}$.

The soils of the experimental area were described as a Rhodic Kandiudox (Nitossolo Vermelho distroférrico) and a Lithic Distrochrept (Cambissolo Háplico $\mathrm{Tb}$ distroférrico léptico); their chemical and physical characteristics are presented in Table 1. Previously, the experimental areas of both soils had been farmed with commercial corn crops in the summer, and oat crops in the winter, from 1994 until 2009. During this period, two limings with $5 \mathrm{Mg}^{-1} \mathrm{ha}^{-1}$ dolomitic limestone were applied and incorporated into the 0.0 to $0.2 \mathrm{~m}$ soil layer, and the area was fertilized with swine manure to supply $80 \mathrm{~kg} \mathrm{ha}^{-1} \mathrm{~N}$ and about $2 \mathrm{Mg} \mathrm{ha}^{-1} \mathrm{C}$, always in the summer cultivations; these practices promoted the construction of the high fertility of these soils.

During the installation of the experiment, the topsoil vegetation was desiccated by the application of glyphosate herbicide (2,2 $\mathrm{kg} \mathrm{ha}^{-1}$ a.i.), after which corn was sown in both soils, for which the agricultural practice was repeated with the same active principle and dose, always with 14-day lead time prior to the 
sowing of the summer crops of 2010/2011, 2011/2012 and 2012/2013 and the winter crops of 2011, 2012, and 2013 crop seasons.

The work was conducted in experiment groups in a randomized complete block design. Each soil class was considered as an individual experiment, involving five treatments of fertilizers and four replicates. Following individual analysis, each experiment were grouped for joint analysis, for which the effect of the fertilizers was tested by the mean square of fertilizer-soil interactions, and the latter effect was tested by the residual mean square of the joint analysis.

The treatments consisted of one control without fertilizer, and four fertilizers, two of which were organomineral, and the other two were mineral fertilizers in solid and fluid form, all in the formulation 03-12-06. The solid mineral fertilizer (MS) was composed of urea, monoammonium phosphate (MAP) and potassium chloride (KC1); the solid organomineral (OS) fertilizer was formulated on a poultry litter basis supplemented with urea, $\mathrm{KC1}$, and natural phosphorous from the municipality of Registro, in the state of São Paulo. The fluid mineral fertilizer (MF) was composed of water, urea, MAP, and $\mathrm{KCl}$; and the fluid organomineral fertilizer (OF) was formulated on a pig slurry basis with added urea, MAP, and $\mathrm{KCl}$.

Pig slurry used to form the OF fertilizer was obtained from finishing swine, via collection from a biodigestor discharge tubing. The chemical properties of swine manure were determined according to Rice et al. (2012) (Table 2). The OS fertilizer consisted of poultry litter, collected after six batches, composed of 20,40 , and $22 \mathrm{~g}$ $\mathrm{kg}^{-1}$ total $\mathrm{N}, \mathrm{P}_{2} \mathrm{O}_{5}$, and $\mathrm{K}_{2} \mathrm{O}$, respectively. For granulation, the poultry litter was micronized and received $0.5 \%$ manioc starch as an aggregation conditioner, and $0.5 \%$ calcium silicate to increase the hardness of the granule.

The fertilizers were applied to the surface and, subsequently, they were incorporated manually into the corn and fodder sorghum crops to attain a $10 \mathrm{Mg} \mathrm{ha}^{-1}$ grain yield, and $8 \mathrm{Mg} \mathrm{ha}^{-1}$ dry mass, respectively, as described by Silva et al. (2016). The $\mathrm{N}$ dose was defined at $150 \mathrm{~kg} \mathrm{ha}^{-1}$, from which $50 \mathrm{~kg} \mathrm{~N}$ were applied to the base with the fertilizers under evaluation (mineral and organomineral), corresponding to an application of

Table 1. Chemical properties and clay content at 0.0-0.2 m soil depths of the Rhodic Kandiudox (Oxisol) and Lithic Distrochrept (Inceptisol) of the selected area prior to installation of the experiment.

\begin{tabular}{|c|c|c|c|c|c|c|c|c|}
\hline Soil & Treatment & $\begin{array}{c}\text { Clay } \\
\left(\mathrm{g} \mathrm{dm}^{-3}\right)\end{array}$ & $\begin{array}{c}\mathrm{pH} \\
\mathrm{H}_{2} \mathrm{O}\end{array}$ & $\begin{array}{c}\mathrm{CO} \\
\left(\mathrm{g} \mathrm{dm}^{-3}\right)\end{array}$ & $\begin{array}{c}\mathrm{P} \\
\left(\mathrm{mg} \mathrm{dm}^{-3}\right)\end{array}$ & \multicolumn{3}{|c|}{--------------( $\left.\mathrm{mmol}_{\mathrm{c}} \mathrm{dm}^{-3}\right)$----------- } \\
\hline \multirow{5}{*}{ Inceptisol } & Control (C) & 690 & 5.7 & 24.5 & 66.9 & 8.3 & 73.8 & 30.3 \\
\hline & Solid mineral (MS) & 660 & 5.7 & 25.5 & 79.5 & 9.4 & 95.9 & 44.7 \\
\hline & Solid organomineral (OS) & 660 & 5.6 & 24.9 & 63.7 & 8.6 & 83.1 & 31.7 \\
\hline & Fluid mineral (MF) & 690 & 5.6 & 23.0 & 63.8 & 7.1 & 97.5 & 40.8 \\
\hline & Fluid organomineral (OF) & 690 & 5.8 & 24.7 & 78.5 & 7.4 & 99.1 & 42.5 \\
\hline \multirow{5}{*}{ Oxisol } & Control (C) & 700 & 5.4 & 25.4 & 83.0 & 8.7 & 64.0 & 32.0 \\
\hline & Solid mineral (MS) & 700 & 5.3 & 25.9 & 78.0 & 8.8 & 59.9 & 32.2 \\
\hline & Solid organomineral (OS) & 700 & 5.3 & 24.2 & 84.0 & 9.1 & 64.3 & 35.5 \\
\hline & Fluid mineral (MF) & 700 & 5.2 & 23.4 & 61.0 & 8.5 & 56.0 & 31.3 \\
\hline & Fluid organomineral (OF) & 700 & 5.3 & 25.4 & 89.7 & 8.3 & 61.8 & 34.2 \\
\hline
\end{tabular}

${ }^{(1)}$ Determined as described by Tedesco et al. (1995). Means of four replicates.

Table 2. Chemical properties of swine manure used to develop the fluid organomineral fertilizer.

\begin{tabular}{|c|c|c|c|c|c|c|c|c|c|}
\hline Sample & Date & $\mathrm{N}$ & $P$ & $\mathrm{~K}$ & $\mathrm{Cu}$ & $\mathrm{Zn}$ & ST & SS & $\mathrm{SD}$ \\
\hline Manure & 2010 & 7.2 & 1.7 & 3.2 & 0.02 & 0.12 & 88.0 & 21.3 & 66.6 \\
\hline Manure & 2011 & 5.0 & 1.1 & 2.8 & 0.04 & 0.17 & 77.7 & 19.0 & 52.6 \\
\hline Manure & 2012 & 2.1 & 1.3 & 1.1 & 0.04 & 0.12 & 70.0 & 19.0 & 51.3 \\
\hline
\end{tabular}

ST, total solids; SS, suspended solids; and SD, dissolved solids. 
$1,667 \mathrm{~kg} \mathrm{ha}^{-1}$ of the $03-12-06$ formulation, and $100 \mathrm{~kg} \mathrm{~N}$ with urea applied to the topsoil. The doses of $\mathrm{P}_{2} \mathrm{O}_{5}$ and $\mathrm{K}_{2} \mathrm{O}$ applied with the different fertilizers were 200 and $100 \mathrm{~kg} \mathrm{ha}^{-1}$, respectively.

The choice of the 03-12-06 $\left(\mathrm{N}-\mathrm{P}_{2} \mathrm{O}_{5}-\mathrm{K}_{2} \mathrm{O}\right)$ formula sought to add a greater $\mathrm{P}$ concentration to achieve a possible residual effect on the black oat and wheat crops, aiming to fertilize the production system both in the two years of corn/oat cultivations and the year of sorghum/ wheat cultivations.

High yield, early cycle single hybrids were used for the corn (Zea mays L.) cultivation, for which the DKB 240 Yieldgard hybrid was used for the 2010/2011 crop season, and the Celeron LT hybrid for the 2011/2012 crop season, both of which are considered highly demanding for soil fertility. In the two black oat (Avena strigosa Schreb) plantations in the winters of 2011 and 2012, the common cultivar was used. In the 2012/2013 crop season, the fodder sorghum (Sorghum vulgare) cultivar BRS 802 was used in the summer period, and in the winter of 2013, the wheat (Triticum aestivum L.) cultivar BRS Parrudo was cultivated.

In the three agricultural years, the corn and wheat grain yields were determined, as well as the shoot dry mass of oat and sorghum. Corn and wheat ears were harvested manually, from $2.0 \mathrm{~m}$ long rows, with a total harvested area per portion of $3.2 \mathrm{~m}^{2}$. A manual threshing, weighing, and drying of the grain were conducted subsequently, with a $13 \%$ moisture correction value considered for yield calculation.

The yields of shoot dry matter of black oat and sorghum crops were determined by weighing of the plants harvested from three $0.25 \mathrm{~m}^{2}$ microportions per experiment unit, which were dried in a forcedair circulation oven at $65^{\circ} \mathrm{C}$ until constant mass was achieved.

For the analyses of carbon in the soil, deformed samples were taken from $0.0-0.05,0.05-0.1,0.1-0.2$ and $0.0-0.2 \mathrm{~m}$ soil depths. OC levels were ascertained in two granulometric fractions corresponding to the particulate organic carbon (POC), characterized by particles with dimensions greater than $53 \mu \mathrm{m}$, and to organic carbon associated to minerals (CAM) characterized by particles with dimensions smaller than $53 \mu \mathrm{m}$, and stock in total organic carbon (TOC) fraction.

POC was determined according to the method described by Cambardella \& Elliot (1992), and CAM was estimated by the difference between TOC and POC.
The TOC of the soil and of the particulate fraction was quantified by the Walkley-Black method, as described by Tedesco et al. (1995), after the samples had been dried at $60^{\circ} \mathrm{C}$ and ground with porcelain pestle and mortar. The stocks of the TOC fraction were estimated by the equivalent soil mass and layer method.

The equivalent layer method takes into consideration the thickness of the layer, soil bulk density, reference soil-equivalent mass and soil mass of a treatment, which is taken as the basis for the calculation of the stock in all other treatments (Ellert \& Bettany, 1995; Bayer et al., 2000). For the present study, the soil masses of the layers corresponding to the native vegetation, which represents the original condition of the soil, were considered as reference. To determine the soil bulk density, undeformed samples were collected in the same layers.

The effect of fertilizations on the OC forms was evaluated in a relative manner by calculating the carbon management index (CMI), represented by the formula: $\mathrm{CMI}=\mathrm{CSI} \times \mathrm{LI} \times 100$, in which CSI stands for the carbon stock index, and LI, the lability index, calculated by the formulae: $\mathrm{CSI}=\mathrm{TOC}_{\text {treatment }} / \mathrm{TOC}_{\text {native vegetation; }}$; and $\mathrm{LI}=\mathrm{L}_{\text {treatment }} / \mathrm{L}_{\text {native vegetation, }}$ as described by Blair et al. (1995). The term L represents the SOM lability in the treatment $\left(\mathrm{L}_{\text {treatment }}\right)$ in relation to the SOM of the reference system $\left(\mathrm{L}_{\text {native vegetation }}\right)$. Lability is represented by the POC (Vieira et al., 2007).

Data were subjected to the homogeneity of variances and normality tests, the analysis of variance was performed by the $\mathrm{F}$ test, following an experimental group design. The treatment means were, then, compared by Tukey's test, protected by the significance of a global F-test. A 5\% probability was adopted as the rate of error for decision-making purposes.

\section{Results and Discussion}

Little change occurred in the total organic carbon (TOC) content in the soil, as a result of the application of organomineral and mineral fertilizers in solid and fluid forms, in the Inceptisol and Oxisol with "constructed fertility" (highly fertile soils) (Table 3), except for the Inceptisol where the fluid mineral fertilizer (MF) increased the TOC content in comparison to the other treatments at $0.0-0.05$ and $0.0-0.2 \mathrm{~m}$ soil depths.

In both experiments (Inceptisol and Oxisol), the highest TOC levels were found at the surface layer 0.0 - 
$0.05 \mathrm{~m}$ (Table 3). These results can be explained by the no-tillage system adopted, which promotes a greater accumulation of TOC in the surface layers due to less turning of the soil (Andrade et al., 2012; Mafra et al., 2014).

In the adjacent cross-section layers at $0.05-0.1$ and 0.1-0.2 $\mathrm{m}$, both the Inceptisol and Oxisol showed no difference between treatments (Table 3). In soils with a long history of fertilizer application and, consequently, the construction of high-fertility of such soils, fertilization by organomineral and mineral fertilizers in solid and fluid forms did not enable further deep soil increases of TOC content.

In soils with high fertility, a large proportion of the chemical and physical attributes are stable, and significant responses caused by the use of fertilizers can be difficult to perceive in the short- and medium terms, with the greatest responses expected in the long-term (Andrade et al., 2010; Costa et al., 2011; Corrêa et al., 2018b).

The total organic carbon stock (TOCs) followed the same behavior of the TOC content, with little change by virtue of the application of organomineral and mineral fertilizers in solid and fluid forms (Table 4). However, the MF and OS treatments were similar for these stocks, and showed - in the Inceptisol only - the highest values at $0.0-0.05$ and $0.0-0.2 \mathrm{~m}$ soil depths.

Applications of mineral fertilizers plus swine manure have proven to elevate the TOCs in soils with medium or low-fertility conditions, which allows of the characterization of a sustainable practice for soil fertility (Zhang et al., 2012; Mafra et al., 2015). Each soil has a TOC capacity limit that can be reached for the adoption of fertilizers and correctives, as they increase the mass yield of crop shoots and roots (Kätterer et al., 2011; Quanyinga et al., 2014; Castro et al., 2015).

For the particulate organic carbon (POC) fraction, a difference was observed in the Inceptisol only, at the 0.05- $0.10 \mathrm{~m}$ soil depths, where the MF treatment resulted in higher results than the other treatments (Table 5). There are similarity levels of POC content at the $0.1-0.2$ and $0.0-0.2 \mathrm{~m}$ soil depths in the Inceptisol and Oxisol, allow us to infer that fertilization by organomineral and mineral fertilizers in solid and fluid form for three years of the experiment. The significant POC response in the Inceptisol could be due to the conditions of betterpreserved clay minerals, thanks to the limited effects of weathering in this soil class, favouring the formation of the clay-metal-humus complex.

In the conditions of this experiment, the POC contents of the treatments with fertilizers were lower than the reference levels of the native vegetation at 0.0 $0.20 \mathrm{~m}$ soil depths, which are $7.9 \mathrm{~g} \mathrm{~kg}^{-1}$ in both soils (Inceptisol and Oxisol). The disturbance caused to the soil as a result of agricultural activity brings about the reduction of different compartments of organic carbon, in comparison to the native vegetation, that is considered as a stable system (Sá et al., 2017).

POC is the organic carbon fraction with a low degree of humification, it is considered labile and readily

Table 3. Total organic carbon contents in Rhodic Kandiudox (Oxisol) and Lithic Distrochrept (Inceptisol), in response to the application of mineral and organomineral fertilizers in solid (MS and OS) and fluid (MF and OF) forms. ${ }^{(1)}$

\begin{tabular}{|c|c|c|c|c|c|c|}
\hline \multirow[t]{2}{*}{ Soil } & \multicolumn{5}{|c|}{ Total organic carbon (TOC) $\left(\mathrm{g} \mathrm{kg}^{-1}\right)$} & \multirow[t]{2}{*}{$\operatorname{Pr}>\mathrm{F}$} \\
\hline & Control & MF & MS & OF & OS & \\
\hline \multicolumn{7}{|c|}{$0.0-0.05 \mathrm{~m}$ soil depths } \\
\hline Inceptisol & $28 \pm 0.96 \mathrm{c}$ & $38 \pm 0.66 \mathrm{a}$ & $32 \pm 2.43 b c$ & $29 \pm 1.52 \mathrm{c}$ & $33 \pm 0.96 \mathrm{~b}$ & 0.0004 \\
\hline Oxisol & $32 \pm 1.40$ & $34 \pm 0.97$ & $35 \pm 1.47$ & $33 \pm 0.89$ & $32 \pm 1.85$ & 0.46 \\
\hline \multicolumn{7}{|c|}{$0.05-0.1 \mathrm{~m}$ soil depths } \\
\hline Inceptisol & $22 \pm 0.69$ & $26 \pm 2.87$ & $23 \pm 0.22$ & $24 \pm 1.03$ & $24 \pm 0.61$ & 0.26 \\
\hline Oxisol & $26 \pm 1.67$ & $28 \pm 1.74$ & $27 \pm 0.82$ & $28 \pm 1.47$ & $26 \pm 0.68$ & 0.63 \\
\hline \multicolumn{7}{|c|}{$0.1-0.2 \mathrm{~m}$ soil depths } \\
\hline Inceptisol & $22 \pm 1.16$ & $23 \pm 0.68$ & $22 \pm 0.12$ & $21 \pm 0.80$ & $24 \pm 0.91$ & 0.27 \\
\hline Oxisol & $24 \pm 1.97$ & $24 \pm 1.21$ & $23 \pm 0.73$ & $23 \pm 0.34$ & $24 \pm 1.21$ & 0.94 \\
\hline \multicolumn{7}{|c|}{$0.0-0.2 \mathrm{~m}$ soil depths ${ }^{(2)}$} \\
\hline Inceptisol & $24 \pm 1.91 \mathrm{c}$ & $27 \pm 1.52 \mathrm{a}$ & $25 \pm 1.66 b c$ & $24 \pm 1.44 \mathrm{c}$ & $26 \pm 0.76 \mathrm{ab}$ & 0.007 \\
\hline Oxisol & $27 \pm 1.70$ & $28 \pm 1.23$ & $27 \pm 1.04$ & $27 \pm 0.99$ & $26 \pm 1.58$ & 0.79 \\
\hline
\end{tabular}

(1)Means followed by equal letters, uppercase represent the difference between soils and lowercase ones represent the difference between treatments, do not differ by the Student's t-test, at 5\% probability. Soil collection at $0.0-0.2 \mathrm{~m}$ soil depths was carried out separately from the other samples. 
influenced by management practices such as fertilization in the soil-plant system (Mafra et al., 2014), which characterizes it as a sensitive and effective indicator in the study of SOM dynamics (Conceição et al., 2013) and allows of the short-term effect of the management to be verified (Bayer et al., 2002). However, the only treatment to represent this modification was the MF in the Inceptisol, that shows an improved soil quality and supports its description as good farming practices.
For carbon contents associated to minerals (CAM), there was a change in both MF and OS fertilizers only in the Inceptisol, which showed higher MF at $0.0-0.5 \mathrm{~m}$ soil depth, and higher MF and OS at 0.0-0.2 m soil depth (Table 2). CAM contents in both soils (Oxisol and Inceptisol), for all the treatments, were lower than the reference levels of the native vegetation, with $26.5 \mathrm{~g} \mathrm{~kg}^{-1}$ at $0.0-0.2 \mathrm{~m}$ depth, showing the CAM loss in this tillage system.

Table 4. Total organic carbon stock in Rhodic Kandiudox (Oxisol) and Lithic Distrochrept (Inceptisol), in response to the application of mineral and organomineral fertilizers in solid (MS and OS) and fluid (MF and OF) forms ${ }^{(1)}$.

\begin{tabular}{|c|c|c|c|c|c|c|}
\hline \multirow[t]{2}{*}{ Soil } & \multicolumn{5}{|c|}{ Total organic carbon stock (TOCs) $\left(\mathrm{g} \mathrm{kg}^{-1}\right)$} & \multirow[t]{2}{*}{$\operatorname{Pr}>\mathrm{F}$} \\
\hline & Control & MF & MS & OF & OS & \\
\hline \multicolumn{7}{|c|}{$0.0-0.05 \mathrm{~m}$ soil depth } \\
\hline Inceptisol & $14.8 \pm 0.50 \mathrm{c}$ & $20.0 \pm 0.35 \mathrm{a}$ & $16.7 \pm 1.27 \mathrm{~b}$ & $12.5 \pm 0.48 \mathrm{ab}$ & $17.6 \pm 0.37 \mathrm{a}$ & 0.001 \\
\hline Oxisol & $17.5 \pm 0.76$ & $18.7 \pm 0.53$ & $19.3 \pm 0.80$ & $18.1 \pm 0.48$ & $17.7 \pm 1.00$ & 0.22 \\
\hline \multicolumn{7}{|c|}{$0.05-0.1 \mathrm{~m}$ soil depth } \\
\hline Inceptisol & $11.1 \pm 0.35$ & $13.4 \pm 1.45$ & $11.8 \pm 0.11$ & $12.2 \pm 0.52$ & $12.1 \pm 0.31$ & 0.14 \\
\hline Oxisol & $13.5 \pm 0.85$ & $14.3 \pm 0.89$ & $13.5 \pm 0.42$ & $14.4 \pm 0.75$ & $13.1 \pm 0.35$ & 0.59 \\
\hline \multicolumn{7}{|c|}{$0.1-0.2 \mathrm{~m}$ soil depth } \\
\hline Inceptisol & $20.4 \pm 1.08$ & $21.1 \pm 0.63$ & $20.0 \pm 0.11$ & $19.2 \pm 0.74$ & $22.1 \pm 0.84$ & 0.44 \\
\hline Oxisol & $21.7 \pm 1.77$ & $21.9 \pm 1.09$ & $21.0 \pm 0.66$ & $21.0 \pm 0.30$ & $21.3 \pm 1.09$ & 0.32 \\
\hline \multicolumn{7}{|c|}{$0.0-0.2 \mathrm{~m}$ soil depth ${ }^{(2)}$} \\
\hline Inceptisol & $46.4 \pm 1.93 \mathrm{Bc}$ & $54.4 \pm 1.66 \mathrm{a}$ & $48.5 \pm 1.56 \mathrm{bc}$ & $46.6 \pm 1.57 \mathrm{bc}$ & $51.8 \pm 1.81 \mathrm{ab}$ & 0.001 \\
\hline Oxisol & $52.6 \pm 1.81 \mathrm{~A}$ & $54.9 \pm 1.79$ & $53.8 \pm 1.71$ & $53.5 \pm 1.49$ & $52 \pm 1.93$ & 0.21 \\
\hline
\end{tabular}

${ }^{(1)}$ Means followed by equal letters, uppercase in the column (Control) and lowercase in the rows, do not differ by Tukey's test, at $5 \%$ probability. ${ }^{\left({ }^{2}\right)}$ Stock values represent the calculation for equivalent mass of soil at $0.0-0.20 \mathrm{~m}$ depths.

Table 5. Particulate organic carbon content and particulate organic carbon stock, in Rhodic Kandiudox (Oxisol) and Lithic Distrochrept Distrochrept (Inceptisol), in response to the application of mineral and organomineral fertilizers in solid (MS and $\mathrm{OS}$ ) and fluid (MF and OF) forms. ${ }^{(1)}$

\begin{tabular}{|c|c|c|c|c|c|c|}
\hline \multirow[t]{2}{*}{ Soil } & \multicolumn{5}{|c|}{ Particulate organic carbon (POC) $\left(\mathrm{g} \mathrm{kg}^{-1}\right)$} & \multirow[t]{2}{*}{$\mathrm{Pr}>\mathrm{F}$} \\
\hline & Control & MF & MS & $\mathrm{OF}$ & OS & \\
\hline \multicolumn{7}{|c|}{$0.0-0.05 \mathrm{~m}$ soil depth } \\
\hline Inceptisol & $6.2 \pm 0.79 \mathrm{~A}$ & $6.9 \pm 0.88$ & $5.6 \pm 0.28$ & $4.7 \pm 0.75$ & $6.1 \pm 0.48$ & 0.17 \\
\hline Oxisol & $4.1 \pm 0.32 \mathrm{~B}$ & $6.6 \pm 0.73$ & $5.6 \pm 0.60$ & $6.0 \pm 0.59$ & $5.2 \pm 0.43$ & 0.10 \\
\hline \multicolumn{7}{|c|}{$0.05-0.1 \mathrm{~m}$ soil depth } \\
\hline Inceptisol & $2.4 \pm 0.19 \mathrm{~b}$ & $2.9 \pm 0.21 \mathrm{a}$ & $2.4 \pm 0.4 \mathrm{Bbc}$ & $2.3 \pm 0.33 \mathrm{Bc}$ & $2.6 \pm 0.12 b$ & 0.26 \\
\hline Oxisol & $2.6 \pm 0.06$ & $3.0 \pm 0.19$ & $3.0 \pm 0.16 \mathrm{~A}$ & $2.6 \pm 0.15 \mathrm{~A}$ & $2.9 \pm 0.17$ & 0.32 \\
\hline \multicolumn{7}{|c|}{$0.1-0.2 \mathrm{~m}$ soil depth } \\
\hline Inceptisol & $1.6 \pm 0.24$ & $1.6 \pm 0.09$ & $1.6 \pm 0.24$ & $1.5 \pm 0.22$ & $2.1 \pm 0.26$ & 0.16 \\
\hline Oxisol & $1.8 \pm 0.11$ & $1.7 \pm 0.16$ & $2.1 \pm 0.21$ & $1.7 \pm 0.18$ & $2.0 \pm 0.10$ & 0.41 \\
\hline \multicolumn{7}{|c|}{$0.0-0.2 \mathrm{~m}$ soil depth ${ }^{(2)}$} \\
\hline Inceptisol & $3.0 \pm 0.43$ & $3.3 \pm 0.57$ & $2.8 \pm 1.29$ & $2.4 \pm 0.47$ & $3.2 \pm 0.24$ & 0.07 \\
\hline Oxisol & $2.6 \pm 0.16$ & $3.2 \pm 0.36$ & $3.2 \pm 0.51$ & $3.0 \pm 0.29$ & $3.0 \pm 0.22$ & 0.29 \\
\hline
\end{tabular}

(1) Means followed by equal letters, uppercase in the columns and lowercase in the rows, do not differ by Tukey's test, at $5 \%$ probability. ${ }^{(2)}$ Soil collection at $0.0-0.2 \mathrm{~m}$ soil depths was carried out separately from the other samples. 
The reduced CAM of the treatments in comparison to the native vegetation is associated to the break of the aggregates in the cultivated areas, by which carbon was exposed to microbial action (Mafra et al., 2015), thus hindering the accumulation of organic carbon in the soil from the application of fertilizers and from the vegetable mass.

Small changes in the CAM of treatments can be explained by the little alterations to which CAM is subjected, which result from different forms of management, as CAM stability is related to interaction with the mineral phase and with the physical protection inside the microaggregates of the soil (Bayer et al., 2004).

The effect of the fertilizers applied to the soil on CAM was similar to that found in the POC, with a greater significance in the surface layer of the Inceptisol (Table 6). POC is considered the best indication of the SOM quality, in comparison to CAM because of the short-term management alterations, as it due to it being less recalcitrant and complex.

In the carbon management index (CMI) there were differences between the treatments only at $0.05-0.1 \mathrm{~m}$ soil depth, in the Inceptisol condition, for which the fertilization with MF and OS were greater than the other treatments (Table 7). These results are similar to those found in the POC for the same cross-section layer of Inceptisol (Table 5).
These CMI results for MF and OS, with values of 52.1 and $42.8 \mathrm{~g} \mathrm{~kg}^{-1}$ for Inceptisol, allows us to infer that these fertilizers promote smaller $\mathrm{C}$ losses in comparison to the other treatments (Table 7). The CMI seems to be a useful information on the best soil management systems, as it integrates, in the same measurement, the variations that occur in the different SOM fractions (Nicoloso et al., 2008).

After three years of applying mineral and organomineral fertilizers in solid and fluid forms in Inceptisol and Oxisol, with "constructed fertility", the CMI values were below 100 at all evaluated soil depths (Table 7). CMI values lower than 100 indicate detrimental practices to TOC maintenance (Blair \& Crocker, 2000), since it represents changes in the OC stocks considered labile in the soil; however they indicate favorable management practices for the maintenance of soil organic matter (Schiavo et al., 2011).

Both in Inceptisol and Oxisol, the fodder sorghum yield of shoot dry matter (DM) responded to mineral and organomineral fertilizers in solid and fluid forms (Table 8). In the Inceptisol, the treatments with OF and OS fertilizers were superior to the other treatments, and in the Oxisol, the DM yield with MF was superior.

For DM yield of black oat, there was a difference between the soils only in 2011, when the Oxisol values were greater than those of the Inceptisol (Table 8). In 2011 and 2012 the highest-DM yield of oat occurred in

Table 6. Organic carbon associated to minerals and organic carbon stock associated to minerals in Rhodic Kandiudox (Oxisol) and Lithic Distrochrept (Inceptisol), in response to the application of mineral and organomineral fertilizers in solid (MS and OS) and fluid (MF and OF) forms ${ }^{(1)}$.

\begin{tabular}{|c|c|c|c|c|c|c|}
\hline \multirow{2}{*}{ Soil } & \multicolumn{5}{|c|}{ Organic carbon associated to minerals (CAM) $\left(\mathrm{g} \mathrm{kg}^{-1}\right)$} & \multirow[t]{2}{*}{$\operatorname{Pr}>\mathrm{F}$} \\
\hline & Control & MF & MS & $\mathrm{OF}$ & OS & \\
\hline \multicolumn{7}{|c|}{$0.0-0.05 \mathrm{~m}$ soil depth } \\
\hline Inceptisol & $22 \pm 1.11 \mathrm{c}$ & $30 \pm 1.55 \mathrm{a}$ & $26 \pm 2.55 b$ & $26 \pm 1.12 \mathrm{Bbc}$ & $27 \pm 0.61 b$ & 0.001 \\
\hline Oxisol & $28 \pm 1.51$ & $28 \pm 0.89$ & $30 \pm 1.02$ & $27 \pm 0.76$ & $27 \pm 1.42$ & 0.63 \\
\hline \multicolumn{7}{|c|}{$0.05-0.1 \mathrm{~m}$ soil depth } \\
\hline Inceptisol & $20 \pm 0.85 \mathrm{~B}$ & $23 \pm 2.82$ & $22 \pm 0.24$ & $22 \pm 1.11$ & $21 \pm 0.57$ & 0.45 \\
\hline Oxisol & $24 \pm 1.62 \mathrm{~A}$ & $25 \pm 1.89$ & $24 \pm 0.91$ & $25 \pm 1.59$ & $23 \pm 0.58$ & 0.63 \\
\hline \multicolumn{7}{|c|}{$0.1-0.2 \mathrm{~m}$ soil depth } \\
\hline Inceptisol & $20 \pm 0.96$ & $21 \pm 0.60$ & $20 \pm 0.14$ & $19 \pm 0.90$ & $22 \pm 0.74$ & 0.39 \\
\hline Oxisol & $22 \pm 1.93$ & $23 \pm 1.12$ & $21 \pm 0.74$ & $22 \pm 0.40$ & $22 \pm 1.13$ & 0.84 \\
\hline \multicolumn{7}{|c|}{$0.0-0.2 \mathrm{~m}$ soil depth ${ }^{(2)}$} \\
\hline Inceptisol & $21 \pm 1.02 \mathrm{c}$ & $24 \pm 1.88 \mathrm{a}$ & $22 \pm 1.42 b c$ & $21 \pm 1.09 \mathrm{bc}$ & $23 \pm 0.71 \mathrm{ab}$ & 0.01 \\
\hline Oxisol & $24 \pm 1.66$ & $25 \pm 1.23$ & $24 \pm 0.93$ & $24 \pm 0.88$ & $23 \pm 1.35$ & 0.84 \\
\hline
\end{tabular}

${ }^{(1)}$ Means followed by equal letters, uppercase in the column (Control) and lowercase in the rows, do not differ by Tukey's test, at $5 \%$ probability. ${ }^{(2)}$ Soil collection at $0.0-0.2 \mathrm{~m}$ soil depths was carried out separately from the other samples. 
the treatment with the OF fertilizer, which was superior to the other treatments both in Oxisol and in Inceptisol. In general, the DM yield for black oats showed a greater residual effect where the OF fertilizer was applied, proving that this fertilizer is superior to the traditional soluble solid form and to the mineral fertilizers in this aspect, in both soil types, and in both years of oat cultivation.

For wheat grain yield in 2013, the use of fertilizers in the mineral form of MF and MS produced a greater yield

Table 7. Carbon management index (CMI) in Rhodic Kandiudox (Oxisol) and Lithic Distrochrept (Inceptisol), in response to the application of mineral and organomineral fertilizers in solid (MS and OS) and fluid (MF and OF) forms ${ }^{(1)}$.

\begin{tabular}{|c|c|c|c|c|c|c|}
\hline \multirow[t]{2}{*}{ Soil } & \multicolumn{5}{|c|}{ Carbon management index $\left(\mathrm{g} \mathrm{kg}^{-1}\right)$} & \multirow[t]{2}{*}{$\operatorname{Pr}>\mathrm{F}$} \\
\hline & Control & MF & MS & $\mathrm{OF}$ & OS & \\
\hline \multicolumn{7}{|c|}{$0.0-0.05 \mathrm{~m}$ soil depth } \\
\hline Inceptisol & $26.8 \pm 1.22 \mathrm{~A}$ & $28.1 \pm 0.65$ & $22.8 \pm 2.43$ & $18.5 \pm 1.72$ & $24.6 \pm 1.14$ & 0.23 \\
\hline Oxisol & $15.6 \pm 1.49 \mathrm{~B}$ & $27.2 \pm 0.99$ & $22.3 \pm 1.62$ & $24.5 \pm 1.52$ & $20.7 \pm 2.06$ & 0.12 \\
\hline \multicolumn{7}{|c|}{$0.05-0.1 \mathrm{~m}$ soil depth } \\
\hline Inceptisol & $39.5 \pm 1.37 b$ & $52.1 \pm 0.91 \mathrm{a}$ & $38.6 \pm 2.69 \mathrm{Bbc}$ & $29.8 \pm 1.88 \mathrm{Bc}$ & $42.8 \pm 1.29 \mathrm{ab}$ & 0.001 \\
\hline Oxisol & $42.5 \pm 1.64$ & $49.2 \pm 1.15$ & $49.3 \pm 1.80 \mathrm{~A}$ & $41.5 \pm 1.66 \mathrm{~A}$ & $47.5 \pm 2.21$ & 0.30 \\
\hline \multicolumn{7}{|c|}{$0.1-0.2 \mathrm{~m}$ soil depth } \\
\hline Inceptisol & $39.7 \pm 1.68$ & $38.9 \pm 1.31$ & $40.6 \pm 2.28$ & $36.4 \pm 2.06$ & $53.2 \pm 1.37$ & 0.17 \\
\hline Oxisol & $44.8 \pm 1.88$ & $40.9 \pm 1.45$ & $53.1 \pm 1.93$ & $41.7 \pm 1.82$ & $48.6 \pm 2.09$ & 0.39 \\
\hline \multicolumn{7}{|c|}{$0.0-0.2 \mathrm{~m}$ soil depth ${ }^{(2)}$} \\
\hline Inceptisol & $33.2 \pm 1.42$ & $36.7 \pm 1.37$ & $31.2 \pm 1.81$ & $25.7 \pm 1.49$ & $36.1 \pm 1.55$ & 0.06 \\
\hline Oxisol & $28.1 \pm 1.96$ & $35.9 \pm 1.33$ & $35.8 \pm 1.54$ & $33.0 \pm 1.56$ & $33.3 \pm 1.46$ & 0.30 \\
\hline
\end{tabular}

${ }^{(1)}$ Means followed by equal letters, uppercase in the columns and lowercase in the rows, do not differ by Tukey's test, at $5 \%$ probability. ${ }^{(2)}$ Soil collection at $0.0-0.2 \mathrm{~m}$ soil depths was carried out separately from the other samples.

Table 8. Estimated yield of corn and wheat grains and shoot dry matter of black oat and fodder sorghum, in response to the application of organomineral and mineral fertilizers, in solid and fluid forms, to Rhodic Kandiudox (Oxisol) and Lithic Distrochrept (Inceptisol) ${ }^{(1)}$.

\begin{tabular}{|c|c|c|c|c|c|c|}
\hline \multirow[t]{2}{*}{ Soil } & \multicolumn{5}{|c|}{ Yield and shoot dry matter $\left(\mathrm{Mg} \mathrm{ha}^{-1}\right)$} & \multirow[t]{2}{*}{$\operatorname{Pr}>F$} \\
\hline & Control & MF & MS & $\mathrm{OF}$ & OS & \\
\hline \multicolumn{7}{|c|}{ Corn - 2010/2011 } \\
\hline Inceptisol & $10.7 \pm 0.56 \mathrm{~b}$ & $14.4 \pm 1.12 \mathrm{a}$ & $14.3 \pm 1.04 \mathrm{a}$ & $13.6 \pm 0.89 \mathrm{a}$ & $12.9 \pm 0.77 \mathrm{ab}$ & 0.001 \\
\hline Oxisol & $10.5 \pm 0.55$ & 11.80 .99 & $12.3 \pm 1.16$ & $12.3 \pm 1.08$ & $12.5 \pm 0.69$ & 0.12 \\
\hline \multicolumn{7}{|c|}{ Corn - 2011/2012 } \\
\hline Inceptisol & $10.0 \pm 1.15 \mathrm{~b}$ & $10.5 \pm 1.82 \mathrm{Bb}$ & $13.1 \pm 1.77 \mathrm{a}$ & $13.9 \pm 1.73 \mathrm{a}$ & $11.0 \pm 1.56 \mathrm{Bb}$ & 0.001 \\
\hline Oxisol & $10.5 \pm 1.21 \mathrm{~b}$ & $12.9 \pm 1.58 \mathrm{Aa}$ & $13.0 \pm 1.96 \mathrm{a}$ & $13.4 \pm 1.88 \mathrm{a}$ & $13.1 \pm 1.31 \mathrm{Aa}$ & 0.001 \\
\hline \multicolumn{7}{|c|}{ Sorghum - 2012/2013 } \\
\hline Inceptisol & $5.9 \pm 0.28 \mathrm{c}$ & $6.1 \pm 0.47 \mathrm{Bbc}$ & $6.5 \pm 0.49 \mathrm{Bb}$ & $8.6 \pm 0.37 \mathrm{a}$ & $8.0 \pm 0.49 \mathrm{a}$ & 0.003 \\
\hline Oxisol & $5.7 \mathrm{c} \pm 0.27$ & $9.7 \pm 0.38 \mathrm{Aa}$ & $8.6 \pm 0.26 \mathrm{Ab}$ & $8.5 \pm 0.31 \mathrm{~b}$ & $8.2 \pm 0.21 \mathrm{~b}$ & 0.001 \\
\hline \multicolumn{7}{|c|}{ Oat - 2011} \\
\hline Inceptisol & $2.4 \pm 0.25 \mathrm{Bc}$ & $4.1 \pm 0.28 \mathrm{Bab}$ & $3.1 \pm 0.33 \mathrm{Bbc}$ & $4.7 \pm 0.72 \mathrm{Ba}$ & $3.1 \pm 0.18 \mathrm{Bbc}$ & 0.002 \\
\hline Oxisol & $3.7 \pm 0.16 \mathrm{Ac}$ & $6.6 \pm 0.31 \mathrm{Ab}$ & $5.0 \pm 0.34 \mathrm{Ab}$ & $6.5 \pm 0.33 \mathrm{Aa}$ & $5.0 \pm 0.46 \mathrm{Ab}$ & 0.001 \\
\hline \multicolumn{7}{|c|}{ Oat - 2012} \\
\hline Inceptisol & $5.5 \pm 0.18 \mathrm{~b}$ & $5.7 \pm 0.23 b$ & $6.0 \pm 0.35 \mathrm{~b}$ & $7.1 \pm 0.44 \mathrm{a}$ & $5.5 \pm 0.22 b$ & 0.003 \\
\hline Oxisol & $4.8 \pm 0.21 \mathrm{~b}$ & $5.8 \pm 0.24 \mathrm{~b}$ & $5.7 \pm 0.29 \mathrm{~b}$ & $6.8 \pm 0.36 \mathrm{a}$ & $5.50 .37 \mathrm{~b}$ & 0.001 \\
\hline \multicolumn{7}{|c|}{ Wheat - 2013} \\
\hline Inceptisol & $2.5 \pm 0.24 \mathrm{c}$ & $4.6 \pm 0.45 \mathrm{a}$ & $4.0 \pm 0.22 \mathrm{ab}$ & $3.5 \pm 0.46 \mathrm{bc}$ & $3.5 \pm 0.46 \mathrm{bc}$ & 0.001 \\
\hline Oxisol & $3.7 \pm 0.50$ & $4.0 \pm 0.83$ & $4.2 \pm 0.43$ & $4.5 \pm 0.37$ & $4.4 \pm 0.31$ & 0.21 \\
\hline
\end{tabular}

${ }^{(1)}$ Means followed by equal letters, uppercase in the columns and lowercase in the rows, do not differ by Tukey's test, at $5 \%$ probability. 
than in the other treatments, in the Inceptisol condition, whereas, in the Oxisol there was no difference between treatments (Table 8).

For corn grain yield in 2010/2011, there were differences only in the Inceptisol, where the MF, MS, $\mathrm{OF}$, and OS fertilizers were superior to the control (Table 8). In the 2011/2012 crop season, the OF and MS fertilizers resulted in greater yields than the other treatments in Inceptisol, while in the Oxisol all fertilizers were superior to the control.

The results obtained for corn and wheat yield and for sorghum and black oat shoot DM (Table 8) are correlated to the variables TOC, POC, CAM, and CMI (Tables 3, 5,6 , and 7). This justifies the higher yields obtained with the MF for corn, in 2010/2011, in the Inceptisol and Oxisol and, in 2011/2012, in the Oxisol, as well as for wheat, in 2013, in the Inceptisol. In these types of soils, the MF proved to be superior to the other fertilizers regarding soil carbon forms.

\section{Conclusions}

1. Organomineral and mineral fertilizers in solid and fluid forms applied to different soil classes with constructed fertility promote changes in the total organic carbon, carbon stock, particulate organic carbon, carbon associate with minerals, and carbon management index, in the treatments with fluid mineral and fluid organomineral only in Inceptisol condition due to the lower degree of weathering.

2. The higher values of carbon management index resulting from fluid mineral in the Lithic Distrochrept allows of the inference to be made about the best management practice for increasing and maintaining carbon in the soil system, justified by the wheat, sorghum, and corn yield results, which were similar to those of the other fertilizers.

\section{References}

ANDRADE, A.P.; MAFRA, A.L.; BALDO, G.R.; PICOLLA, C.D.; BERTOL, I.; ALBUQUERQUE, J.A. Physical properties of a Humic Cambisol under tillage and cropping systems after 12 years. Revista Brasileira de Ciência do Solo, v.34, p.219-226, 2010. DOI: https://doi.org/10.1590/S0100-06832010000100022.

ANDRADE, A.P.; MAFRA, A.L.; PICOLLA, C.D.; ALBUQUERQUE, J.A.; BERTOL, I. Atributos químicos de um Cambissolo Húmico após 12 anos sob preparo convencional e semeadura direta em rotação e sucessão de culturas. Ciência
Rural, v.42, p.814-821, 2012. DOI: https://doi.org/10.1590/S010384782012005000013.

BAYER, C.; MIELNICZUK, J.; AMADO, T.J.C.; MARTINNETO, L.; FERNANDES, S.A. Organic matter storage in a sandy clay loam Acrisol affected by tillage and cropping systems in Southern Brazil. Soil \& Tillage Research, v.54, p.101-109, 2000. DOI: https://doi.org/10.1016/S0167- 1987(00)00090-8.

BAYER, C.; MIELNICZUK, J.; MARTIN-NETO, L.; ERNANI, P.R. Stocks and humification degree of organic matter fractions as affected by no-tillage on a subtropical soil. Plant and Soil, v.238, p.133-140, 2002. DOI: https://doi.org/10.1023/A:1014284329618.

BAYER, C.; MARTIN-NETO, L.; MIELNICZUK, J.; PAVINATO, A. Armazenamento de carbono em frações lábeis da matéria orgânica de um Latossolo Vermelho sob plantio direto. Pesquisa Agropecuária Brasileira, v.39, p.677-683, 2004. DOI: https://doi. org/10.1590/S0100-204X2004000700009.

BLAIR, G.J.; LEFROY, R.D.B.; LISLE, L. Soil carbon fractions, based on their degree of oxidation, and the development of a carbon management index for agricultural systems. Australian Journal of Agricultural Research, v.46, p.1459-1466, 1995. DOI: https://doi. org/10.1071/AR9951459.

BLAIR, N.; CROCKER, G.J. Crop rotation effects on soil carbon and physical fertility of two Australian soils. Australian Journal of Soil Research, v.38, p.71-84, 2000. DOI: https://doi.org/10.1071/ SR99064.

CAMBARDELLA, C.A.; ELLIOT, E.T. Particulate soil organicmatter changes across a grassland cultivation sequence. Soil Science Society of America Journal, v.56, p.777-783, 1992. DOI: https://doi.org/10.2136/sssaj1992.03615995005600030017x.

CASTRO, G.S.A.; CRUSCIOL, C.A.C.; CALONEGO, J.C.; ROSOLEM, C.A. Management impacts on soil organic matter of tropical soils. Vadose Zone Journal, v.14, p.1-8, 2015 DOI: https:// doi.org/10.2136/vzj2014.07.0093.

CHRISTENSEN, B.T. Physical fractionation of soil and structural and functional complexity in organic matter turnover. European Journal of Soil Science, v.52, p.345-353, 2001. DOI: https://doi. org/10.1046/j.1365-2389.2001.00417.x.

CONCEIÇÃO, P.C.; DIECKOW, J.; BAYER, C. Combined role of no-tillage and cropping systems in soil carbon stocks and stabilization. Soil \& Tillage Research, v.129, p.40-47, 2013. DOI: https://doi.org/10.1016/j.still.2013.01.006.

CONCEIÇÃO, P.C.; BAYER, C.; DIECKOW, J.; SANTOS, D.C. dos. Fracionamento físico da matéria orgânica e índice de manejo de carbono de um Argissolo submetido a sistemas conservacionistas de manejo. Ciência Rural, v.44, p.794-800, 2014. DOI: https://doi. org/10.1590/S0103-84782014005000004.

CORRÊA, J.C.; GROHSKOPF, M.A.; REBELLATTO, A.; RIGO, A.Z.; COLDEBELLA, A. Fertilization of high-yield corn with poultry litter based on nitrogen doses. Pesquisa Agropecuária Brasileira, v.53, p.342-350, 2018a. DOI: https://doi.org/10.1590/ s0100-204x2018000300009.

CORRÊA, J.C.; REBELLATTO, A.; GROHSKOPF, M.A.; CASSOL, P.C.; HENTZ, P.; RIGO, A.Z. Soil fertility and agriculture yield with the application of organomineral or mineral 
fertilizers in solid and fluid forms. Pesquisa Agropecuária Brasileira, v.53, p.633-640, 2018b. DOI: https://doi.org/10.1590/ S0100-204X2018000500012.

COSTA, M.S.S. de M.; PIVETTA, L.A.; COSTA, L.A. de M.; PIVETTA, L.G.; CASTOLDI, G.; STEINER, F. Atributos físicos do solo e produtividade do milho sob sistemas de manejo e adubações. Revista Brasileira de Engenharia Agrícola e Ambiental, v.15, p.810-815, 2011. DOI: https://doi.org/10.1590/ S1415-43662011000800007.

ELLERT, B.H.; BETTANY, J.R. Calculation of organic matter and nutrients stored in soils under contrasting management regimes. Canadian Journal of Soil Science, v.75, p.529-538, 1995. DOI: https://doi.org/10.4141/ cjss95-075.

KÄTTERER, T.; BOLINDER, M.A.; ANDRÉN, O.; KIRCHMANN, H.; MENICHETTI, L. Roots contribute more to refractory soil organic matter than above-ground crop residues, as revealed by a long-term field experiment. Agriculture, Ecosystems and Environment, v.141, p.184-192, 2011. DOI: https://doi. org/10.1016/j.agee.2011.02.029.

KARHU, K.; GÄRDENÄS, A.I.; HEIKKINEN, J.; VANHALA, P.; TUOMI, M.; LISKI, J. Impacts of organic amendments on carbon stocks of an agricultural soil - Comparison of model-simulations to measurements. Geoderma, v.189-190, p.606-616, 2012. DOI: https://doi.org/10.1016/j.geoderma.2012.06.007.

MAFRA, M.S.H.; CASSOL, P.C.; ALBUQUERQUE, J.A.; CORREA, J.C.; GROHSKOPF, M.A.; PANISSON, J. Acúmulo de carbono em Latossolo adubado com dejeto líquido de suínos e cultivado em plantio direto. Pesquisa Agropecuária Brasileira, v.49, p.630-638, 2014. DOI: https://doi.org/10.1590/s0100$204 \times 2014000800007$.

MAFRA, M.S.H.; CASSOL, P.C.; ALBUQUERQUE, J.A.; GROHSKOPF, M.A.; ANDRADE, A.P.; RAUBER, L.P.; FRIEDERICHS, A. Organic carbon contents and stocks in particle size fractions of a typic hapludox fertilized with pig slurry and soluble fertilizer. Revista Brasileira de Ciência do Solo, v.39, p.1161-1171, 2015. DOI: https://doi.org/10.1590/01000683rbcs20140177.

MCCARTHY, J.F.; ILAVSKY, J.; JASTROW, J.D.; MAYER, L.M.; PERFECT, E.; ZHUANG, J. Protection of organic carbon in soil microaggregates via restructuring of aggregate porosity and filling pores with accumulating organic matter. Geochimica et Cosmochimica Acta, v.72, p.4724-4744, 2008. DOI: https://doi. org/10.1016/j. gca.2008.06.015.

NICOLOSO, R. da S.; LOVATO, T.; AMADO, T.J.C.; BAYER, C.; LANZANOVA, M.E. Balanço do carbono orgânico no solo sob integração lavoura-pecuária no Sul do Brasil. Revista Brasileira de Ciência do Solo, v.32, p.2425-2433, 2008. DOI: https://doi. org/10.1590/S0100-06832008000600020.

QUANYING, W.; YANGB, W.; QICUNA, W.; JINGSHUANGA, L. Impacts of 9 years of a new conservational agricultural management on soil organic carbon fractions. Soil \& Tillage Research, v.143, p.1-6, 2014. DOI: https://doi.org/10.1016/j.still.2014.05.004.

RICE, E.W.; BAIRD, R.B.; EATON, A.D.; CLESCERI, L.S. (Ed.). Standard methods for the examination of water and wastewater. $22^{\text {nd }}$ ed. Washington: American Public Health Association, 2012. $1360 \mathrm{p}$.

SÁ, J.C. de M.; TIVET, F.; LAL, R.; BRIEDIS, C.; HARTMAN, D.C.; SANTOS, J.Z. dos; SANTOS, J.B. dos. Long-term tillage systems impacts on soil $\mathrm{C}$ dynamics, soil resilience and agronomic productivity of a Brazilian Oxisol. Soil \& Tillage Research, v.136, p.38-50, 2014. DOI: https://doi.org/10.1016/j.still.2013.09.010.

SÁ, J.C. de M.; LAL, R.; CERRI, C.C.; LORENZ, K.; HUNGRIA, M.; CARVALHO, P.C. de F. Low-carbon agriculture in South America to mitigate global climate change and advance food security. Environment International, v.98, p.102-112, 2017. DOI: https://doi.org/10.1016/j.envint.2016.10.020.

SCHIAVO, O.A.; ROSSET, J.S.; PEREIRA, M.G.; SALTON, J.C. Índice de manejo de carbono e atributos químicos de Latossolo Vermelho sob diferentes sistemas de manejo. Pesquisa Agropecuária brasileira, v.46, n.10, p.1332-1338, 2011. DOI: https://doi.org/10.1590/S0100-204X2011001000029.

SILVA, L.S.; GATIBONI, L.C.; ANGHINONI, I.; SOUZA, R.O. (Ed.). Manual de calagem e adubação para os estados do Rio Grande do Sul e de Santa Catarina. [S. 1.]: Comissão de Química e Fertilidade do Solo - RS/SC, 2016. 376p.

ŠIMON, T. The influence of long-term organic and mineral fertilization on soil organic matter. Soil \& Water Research, v.3, p.41-51, 2008. DOI: https://doi.org/10.17221/21/2008-SWR.

TEDESCO, M.J.; GIANELLO, C.; BISSANI, C.A.; BOHNEN, H.; VOLKWEISS, S.J. Análises de solo, plantas e outros materiais. 2.ed. rev. e ampl. Porto Alegre: UFRGS, 1995. 212p. (UFRGS. Boletim técnico, 5).

VIEIRA, F.C.B.; BAYER, C.; ZANATTA, J.A.; DIECKOW, J.; MIELNICZUK, J.; HE, Z.L. Carbon management index based on physical fractionation of soil organic matter in an Acrisol under long-term no-till cropping systems. Soil \& Tillage Research, v.96, p.195-204, 2007. DOI: https://doi.org/10.1016/j.still.2007.06.007.

WU, T.; SCHOENAU, J.J.; LI, F.; QIAN, P.; MALHI, S.S.; SHI, Y.; XU, F.; Influence of cultivation and fertilization on total organic carbon and carbon fractions in soils from the Loess Plateau of China. Soil \& Tillage Research, v.77, p.59-68, 2004. DOI: https:doi.org/10.1016/j.still.2003.10.002.

ZHANG, J.B.; ZHU, T.B.; CAI, Z.C.; QIN, S.W.; MÜLLER, C. Effects of long-term repeated mineral and organic fertilizer applications on soil nitrogen transformations. European Journal of Soil Science, v.63, p.75-85, 2012. DOI: https://doi.org/10.1111/ j.1365-2389.2011.01410.x. 